\title{
Landscape construction and time reckoning in Iron Age Celtic Iberia
}

\author{
A. César González-García ', Marco V. García Quintela ${ }^{2}$ and Juan A. Belmonte3 \\ 1 Instituto de Ciencias del Patrimonio (CSIC), Santiago de Compostela, ES \\ a.cesar.gonzalez-garcia@incipit.csic.es \\ 2 University of Santiago de Compostela, ES \\ marco.garcia.quintela@usc.es \\ 3 Instituto de Astrofísica de Canarias Q Astrophysics Department, ULL, La Laguna, ES \\ jba@iac.es
}

\begin{abstract}
In this paper, we report on three areas of the Iberian Peninsula that were occupied at least during the Iron Age and the early stages of Romanisation, where observations of astronomical phenomena in the landscape, rock carvings, and Latin inscriptions point to a particular method of time reckoning. All of these sites have previously been connected with the Celtic culture. The knowledge of the natural world that Classical sources assigned to these peoples need not have been reflected in a monolithic calendrical system used by all Celtic communities on the Continent. In fact, such a 'Celtic calendar' may have had different expressions in different areas, expressed in different ways, although sharing some common characteristics such as the particual use of the lunar and solar cycles.

IZVLEČEK - V članku poročamo o treh območjih na Iberskem polotoku, ki so bila poseljena vsaj od železne dobe in začetka romanizacije, kjer smo na podlagi opazovanj astronomskih fenomenov $v$ pokrajini, na podlagi skalnih rezbarij in latinskih napisov prepoznali posebno metodo merjenja časa. Vsa predstavljena najdišča so bila doslej povezana s keltsko kulturo. Znanje o naravi in svetu, $k i$ so ga klasični viri pripisali Keltom, se ni nujno odražalo v monolitskem koledarskem sistemu, ki so ga uporabljale vse keltske skupnosti na celini. Takšen 'keltski koledar' se je lahko v različnih območjih izražal na drugačne načine, vendar je pri tem ohranil nekatere skupne značilnosti, kot je npr. posebna uporaba Luninih in Sončevih ciklov.
\end{abstract}

KEY WORDS - archaeoastronomy; cultural astronomy; calendars; Celtic Spain

\section{Introduction}

A calendar reflects a particular conception of time constructed to meet the needs of a given society. How this time reckoning may have been first observed and recognised and later reflected in a calendrical system is a matter of debate (see e.g., Marshack 1985 and references thereafter), also taking into account its symbolic implications, as they are well known from the classical work by Martin P. Nilsson (1920).

In this paper, we report on three areas in the Iberian Peninsula that were used at least during the Iron Age and the early stages of Romanisation, where observa- tions of astronomical phenomena in the landscape, rock carvings and Latin inscriptions point to a particular method of time reckoning which may be seen as attempts at establishing a calendrical system. These sites are the rock art area of Campo Lameiro in the province of Pontevedra (Spain), the Panoias Sanctuary, near Vila Real in the North of Portugal, and the Celtiberian site of Peñalba de Villastar, next to the town of Teruel (Spain; Fig. 1). All of them are sites which have been well known for decades, although a number of profound revisions have been carried out in recent years, and we had the opportunity to 
carry out field work at all three of them. All of these sites have been previously connected with the Celtic culture.

A critical view of the European second Iron Age has led to what has been referred to as 'Celt-scepticism' (Merriman 1987; Hill 1993; SimsWilliams 1998; James 1999). This view was inspired mainly by an indepth re-examination of the archaeological evidence presented by scholars of the $19^{\text {th }}$ and early $20^{\text {th }}$ centuries (Collis 2003; Brunaux 2006). Nevertheless, the samples of data, analyses and studies accumulated over the last century in areas of knowledge other than archaeology, highlight the presence of shared cultural forms by Celtic language speakers, who also present diverse forms of social organisation, and who lack-

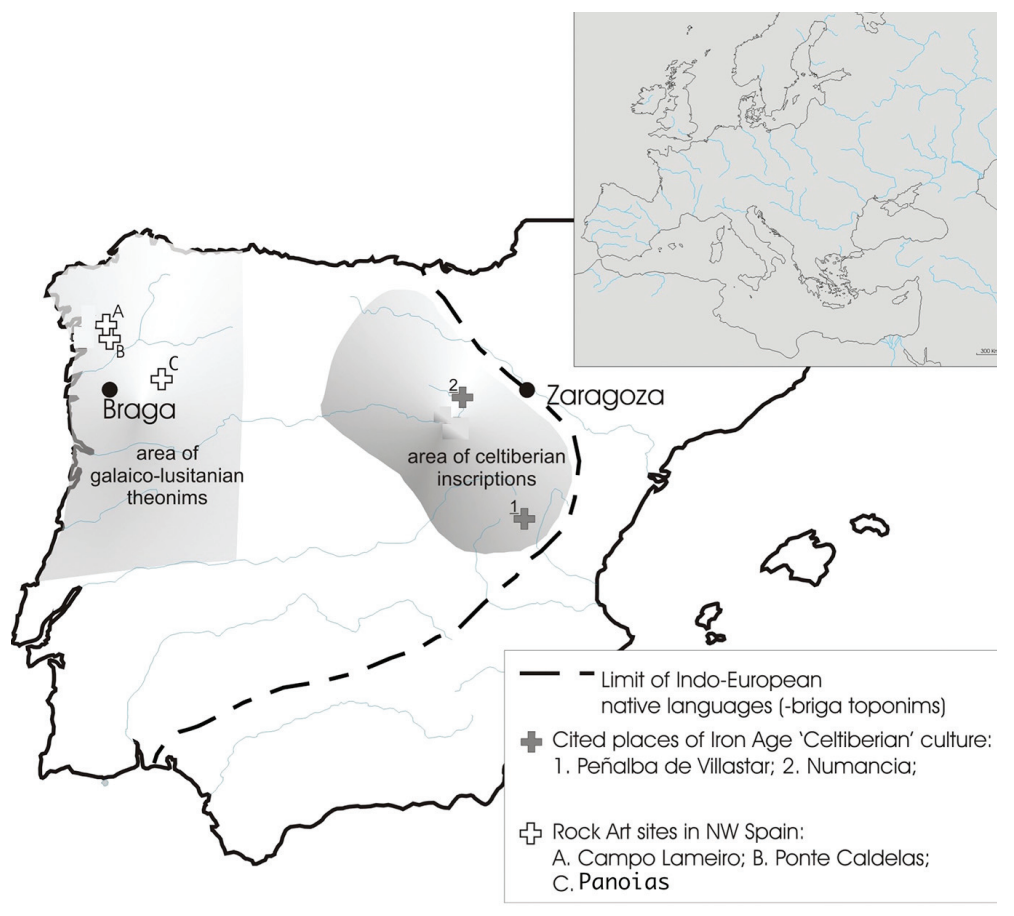

Fig. 1. Iberian Peninsula sites and cities mentioned in the text. ed a common political structure (like, for example, the Ancient Greeks; Megaw, Megaw 1996). Thus, we face the apparent paradox of the presence and $a b-$ sence of the Celts. Possibly, following Simon James (1999), the traditional understanding of the term 'Celtic' might be misleading, and those societies were more varied than usually assumed. Not all 'Celts' may have shared a common 'cultural package'; however, some common features could have been shared in some instances. Arguably, how time was managed in a broad sense could be one of these and deserves investigation.

According to the traditional view, the Celts were reluctant to adopt writing, a common cultural fact in the Indo-European tradition (Sergent 2005). The only written records about them come after inspiring ethnographers from antiquity (Tierney 1960; Nash 1976), by adopting writing from other cultures (Jordán 2007; Lejeune 1985; 1988) or after the introduction of a new cultural/religious manifestation, such as Christianity (as happened in early medieval Ireland).

\section{Celtic calendar}

As mentioned above, one of the supposedly common cultural aspects could be the Celtic calendar. However, this requires a renewed study in order to reveal its religious, cultural and intellectual frameworks, and the likely differences among varying Celtic areas.

In fact, a large part of our knowledge of the Celtic calendar relies only on the Coligny calendar.

The Coligny calendar was discovered in 1897 at Coligny, $100 \mathrm{~km}$ North of Lyon in France. It is comprised of several dozen broken fragments containing Gallic language inscriptions in Latin script dated on a palaeographical basis to the end of the second century $\mathrm{AD}$. The inscriptions are arranged in sets of twelve groups repeated five times, which seems to point to a series of 5 lunar years of 12 months, with each month having either 30 or 29 days. There also seems to be the possibility of introducing intercalary months at appropriate times (Duval, Pinault 1986; see also McCluskey 1990).

In a paper published in 1904 , J. Loth pointed out the parallelism between the temporal notations in the Coligny calendar and the temporal formulae present in modern Celtic languages and folklore (Loth 1904; in a similar line, see Duval, Pinault 1986; Laurent 1995). The foundation for such a calendar would have been the knowledge of astronomical phenomena that Graeco-Latin ethnography attributed to the Druids (see, e.g., Caesar, De bello gallico VI, 18; Pliny, Naturalis historia XVI, 95; Diodorus of Sicily V, 31; Strabo IV, 4,4) and, to the Celtiberians of ancient Iberia (Strabo III, 4, 16).

However, it is one thing to identify and admit this type of knowledge, and quite another to state what 
this knowledge was about. What celestial phenomena did they identify? For example, it is interesting to note that Julius Caesar (De bello gallico VI, 14, 3) mentions that Gallic druids were trained over a 20year period. Could this period be related to a knowledge of the Metonic lunar cycle of 19 years within the framework of the general astronomical science attributed to the druids? Also, it is necessary to establish the temporal and geographic dimensions of this knowledge (Gaspani, Cernuti 1997; Gaspani 1999; Kruta et al. 2008). Did the traditionally claimed Celtic tribes throughout Europe share this knowledge, or were there differences among them?

In this case, it is important not to rush to conclusions. Instead, we must design a methodology to study the relationship between landscape and time in places and periods where the consideration of the Celtic cultural background is firmly based. In the present paper, we present the results of a preliminary attempt to investigate the differences and similarities in time reckoning systems from three sites in Iberia traditionally linked with that Celtic milieu.

When dealing with calendrical issues, it is important to note the problem of incommensurability. This problem arises due to the inequality of the solar and lunar cycles. The simplest way to accommodate both is the three-year cycle with 37 months; 37 synodic lunar months amount to 1092.61 days, while 3 tropic solar years are 1095.73 days, or just three days' difference 1 .

\section{Iron Age 'Celtic' Iberia}

The Iberian Peninsula has commonly been neglected by traditional continental Celtic studies, basically due to the absence of the La Tène style art. However, it must be stressed that, other than Gaul, Classical writers use the term 'Celtic' to describe several tribes in Iberia (James 1993). Alberto Lorrio and Gonzalo Ruíz Zapatero (2005) offer a general characterisation of the period between the end of the Bronze Age and the Iron Age in the Iberian Peninsula, and discuss the problems posed by the Celtic question in Iberia.

From the Roman conquest of the Iberian northwest in $19 \mathrm{BC}$, there are theonyms and anthroponyms together with toponyms in Celtic language that coexisted with another language, to an extent that is still debated, conventionally known as 'Lusitanian' (Prósper 2002.311-312, 357-382; De Bernardo, García Quintela 2008). The Celtiberian area, in central Iberia, is where most texts in a Celtic language have been recorded from antiquity. These were first written in paleo-Hispanic characters and later in the Latin alphabet (Jordán 2007; 2008). We must bear in mind that in both cases, we face situations of cultural intersection.

There are some precedents to our study linking the landscape and the sky in several archaeological sites in the Celtic-speaking area of the Iberian Peninsula. Juan Antonio Belmonte and Michael Hoskin (2002) indicate that the 'verracos', sculptures created by the Vettons in central Spain (Toros de Guisando, Ávila, Spain) face the sunrise at the equinox. However, this could be a unique case, as no systematic study on these sculptures has followed this first attempt. The sanctuary of Ulaca belongs to the same culture, and was recently reported as having some astral connections (Pérez Gutiérrez 2008). Isabel Baquedano and Carlos M. Escorza $(1998 ; 2008)$ report that the stelae in the necropolis of La Osera are also oriented with respect to the skies, notably with some stars, to some extent. Among the Celtiberians, Manuel Pérez and Francisco Burillo (2009) claim that a peculiar, possibly ritual, building found on the outskirts of Segeda is aligned with summer solstice sunset (Pérez, Burillo 2009). Necropolises such as Tiermes (Argente, Díaz and Bescós 2001) and Herrería (Rodríguez et al. 2007) have been claimed to include astronomical orientations, although these are highly debatable. Finally, Luis Valdés (2005) links the orientations at the Iron Age sanctuary of Gastiburu in the Basque Country with control of a seasonal calendar. Also, the rock art site of A Ferradura (Ourense) in Galicia has several engraved panels that have been linked with astronomical alignments (García Quintela, Santos Estévez 2008).

All these works point towards a possible interest in devising and perhaps using some kind of time-reckoning system. Most are linked to the sun and perhaps the moon, although for some of them stellar alignments are also investigated. However, it is difficult to draw a common picture from these analyses. All of these studies lack the general treatment and methodology we are seeking, including a truly interdisciplinary approach. While each individual study offers a sound and scientific treatment of the

1 This simple system has been proposed before for different cultures both in the Mediterranean (e.g., Ancient Greek calendars may have incorporated cycles of this kind; see Hannah 2005) and in the Canary Islands (Belmonte, Hoskin 2002.235-42). 
data, we believe the way to advance further is by exploring the data simultaneously from several points of view.

Therefore, we begin by discussing the methodology of our approach. Secondly, we develop study cases. We then situate the results within the framework of the religious and historic context and the symbolic structure of the landscape in order to finally reach a series of conclusions and propose further work for the future.

\section{Disciplines and methods}

Calendar studies find their place necessarily at a crossroads of disciplines. The first issue is the relationship between calendar and landscape. A number of authors argued that the normal perception of reality in different societies begins with space (Bender 2002; Criado 1989; 1999; Ingold 1993), and with other interests (Levinson 2003; Burenhult, Levinson 2008). Filling in the landscape with content helps to apprehend a territory. This can be achieved by associating tales that give meaning to the natural landscape, or by building monuments.

Using this general idea as our starting point, we based our research on the tenets of landscape archaeology. This perspective considers that societies always leave a 'footprint' in space at several levels of intensity. These footprints may overlap in several ways with older ones, leaving a more or less firm imprint, leading us to read the landscape as a palimpsest. However, each human group in a given territory assumes the landscape completely or in part according to its own intellectual code. In other words, a landscape, i.e. the natural and/or artificial elements placed in a given space, forms part of the present in each historical moment, regardless of when they were built or created (Parcero et al. 1998).

Secondly, from an archaeoastronomical point of view, we are faced with the duality of the possible methodologies. On the one hand, there is 'ethnographic' archaeoastronomy, which considers architectural alignments with heavenly bodies detected in historic contexts according to knowledge derived from written and/or oral sources 2 . On the other hand, 'statistical' archaeoastronomy mainly operates by studying possible statistical regularities in prehistoric re- mains. The two perspectives are not contradictory, as they merely refer to the way of adapting the investigation to the available information resources, and most archaeoastronomical studies include both approaches to a certain degree (see Iwaniszewski 2009 and Ruggles 2011 for recent papers on these issues).

Thirdly, the temporal and cultural framework (see below) allows us to introduce the comparative method of the history of religions. The Indo-European horizon presents a well-known framework of reference on the symbolic plane identified by landscape archaeology (García Quintela, Santos Estévez 2008). With respect to archaeoastronomy, the same Celtic cultural horizon allows to contrast the astronomical observations with ethno-historic evidences. This said, the places studied are not outside the historical process and, as we will see, including Latin inscriptions, and also the Christian saints who were/ are worshiped in these landscapes, provide additional strata of information and meaning that are worthy of inclusion within the general interpretative framework.

Of course, other disciplines could have been applied, but given the nature of the investigation presented below, we considered that these methodologies were the most fitted for the problem that concerns us: how these peoples may have imprinted their sense of time, their calendar and perhaps their rituals on the landscape, and whether we can learn something about their notion of time by studying their archaeological remains. It will finally be interesting to see how this picture contrasts with traditional views on the Celtic calendar.

In order to address these questions, we endeavoured to make a series of archaeoastronomical measurements at the several sites of interest. After determining the direction from which to set the orientation, we take the azimuth for this direction by using two tandems including a precision compass and an inclinometer; one is a Suunto $360 \mathrm{PC} / 360 \mathrm{R}$ and the other a Silva Surveymaster. The error of an individual reading judged by the scale of the instrument is $\pm 1 / 4^{\circ}$ for the azimuth and $\pm 1 / 2^{\circ}$ for the height of the horizon. Note that the individual azimuth determined will have a larger possible error due to, above all, the condition of some of the remains measured.

\footnotetext{
2 This type of investigation also relies on iconography and other types of contextual evidence. It should not be confused with another methodology also called 'ethnoastronomy', which is the study of astronomical concepts in ethnographically documented societies.
} 
Since the instruments used are magnetic, we correct magnetic declination readings. This value was estimated for the fieldwork dates from the models available in http://www.ngdc.noaa.gov.

The data can be compared with estimates for celestial objects visible in that section of the horizon. To perform this comparison, our measurements were translated to declination, resulting in an error estimate around $1^{\circ}$.

\section{Calendars and landscape}

\section{Campo Lameiro: carved deer and time reck- oning}

The prehistoric rock carvings found in the northwest of the Iberian Peninsula are among the most important of this type of artistic manifestation. Discovered between the 1920s and 1930s (Sobrino 2000), they have been studied fundamentally from a formal, chronological and inventory-based perspective. These carvings are concentrated in the southwest of Galicia, coinciding with the present-day Spanish province of Pontevedra, although more and more carvings are appearing in other zones, not always in the same style. Also, the carvings do not appear at random, but are situated at specific points and on specific rocks, and arranged in patterns that are discovered little by little, as they are not always easy to determine. The largest concentration of these carvings ap-
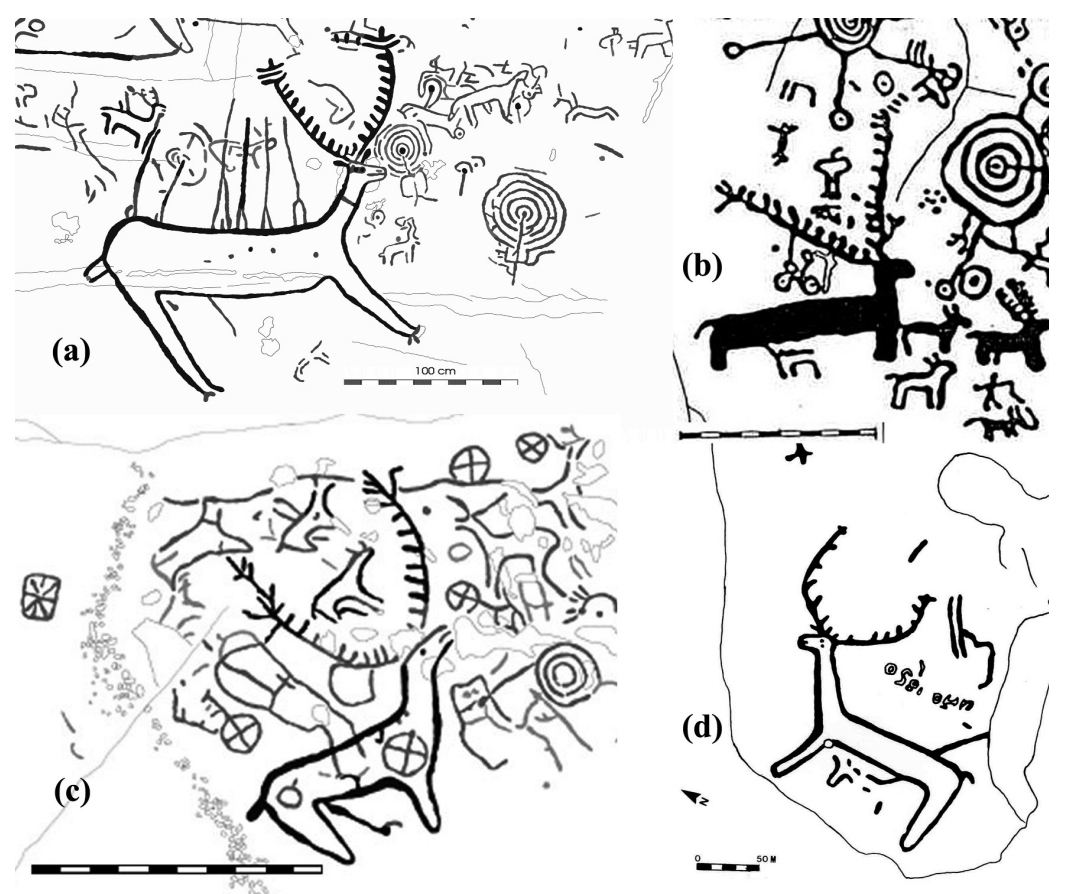

Fig. 2. The four great deer: a Laxe dos Carballos and c Rotea de Mendo are located in Campo Lameiro, while b Laxe das Cruces and d Campo de Cuñas are located in Ponte Caldelas. pears in the area known as Campo Lameiro. This area includes carvings of great variety, including circular motifs (spirals and labyrinths), swords, and many others, with only two written inscriptions in Latin. Among the different motifs that they include, deer are the most important (Santos Estévez 2008b).

Carved deer appear forming herds and, on some occasions in hunting scenes (Peña-Santos, VázquezVarela 1996.41-58; Peña-Santos, Rey-García 2001). The common size of these deer is between 40 to $50 \mathrm{~cm}$ (Santos Estévez, per. comm.), and here we consider four in which an oversized deer (mean of $100 \mathrm{~cm}$ ) is represented. These are in Laxe dos Carballos and Rotea de Mendo (both in Campo Lameiro), Laxe das Cruces and Campo de Cuñas (both in Ponte Caldelas, an area some $20 \mathrm{~km}$ from Campo Lameiro). They are the largest of the carved deer known in Galicia (Fig. 2). In three out of four cases, a 'great deer' dominates an unusually complex carved panel and has an unnatural number of tines per antler. Only the one at Campo de Cuñas (our fourth great deer) appears alone.

Previous studies have linked the petroglyphs in Galicia with calendric issues. Alonso Romero (1983) found some numerical relations on the carved panels from Muros (Pontevedra) that he interpreted as calendric. A dual time-reckoning system (solstices and mid-season Celtic feasts) was identified in the engraved rocks of the Ferradura area (Ourense) (García Quintela, Santos Estévez 2008.231295). But both proposals are limited to isolated cases. The case we will now present possibly overcomes this handicap.

The carvings considered in this study are located at a series of places with common characteristics at which we find huge deer at sites where astronomical events might be witnessed in particular areas of the horizon. Moreover, these deer present an 'abnormal' number of tines in their antlers. Their representation is not 'naturalistic'. Arguably, apart from the landscape orientations, a possible way of counting the tines may link them with a calendrical meaning. This is the case with three of our four great deer. 
Laxe dos Carballos (Fig. 2a) is the only carved panel with a relevant adjacent and datable stratigraphy out of the fifteen or so excavated in Galicia over the last ten years. Radiocarbon dating gives $800 \mathrm{BC}$ as a date post quem relevant to these carvings (Santos Estévez 2008a).

The iconographic and topographic characteristics of the great deer and panel of Laxe dos Carballos are:

(1) The deer is much larger than the average size of those in the region.

(2) The deer faces right.

3 The horizon is open to the southeast.

(4) This horizon has significant astronomical events (solstices and/or lunastices).

5 The deer is in front of a large, circular motif, surrounded by other smaller similar motifs 3 .

(6) A carving is located within the antlers.

- The antlers have an excessive number of tines (i.e. $\geq 11$, as opposed to the standard of 7 in smaller deer).

8 There are three isolated 'strokes' beside the right antler.
(9 The way of counting the number of tines could evoke an 'astronomical' number $(12,13,15,30)$.

The distant horizon from Laxe dos Carballos opens to the southeast (see Tab. 1), and it is in this direction that we find the only two written inscriptions in all Campo Lameiro: two rocks with the Latin text DIVI. They are located at the top of two low hills on a ridge in front of that far horizon, which is itself dominated by a distant mountain. Around 800 BC, sunrise at the winter solstice and moonrise at the southern major lunastice (SML) occurred close to the locations of the rocks inscribed later with the two DIVI inscriptions (Fig. 3; Tab. 1) 4 , i.e. the most southerly rising position of both celestial bodies.

Arguably, the number of tines in the antlers and the way they are distributed may evoke some interesting astronomical numbers (see Fig. 4): 12 is the number of lunar months in a single solar year, while (12 $+3) \times 2=30$ is the whole number of days in a lunar month. We might also count the tines in a sequence suggested by the three isolated strokes next to the

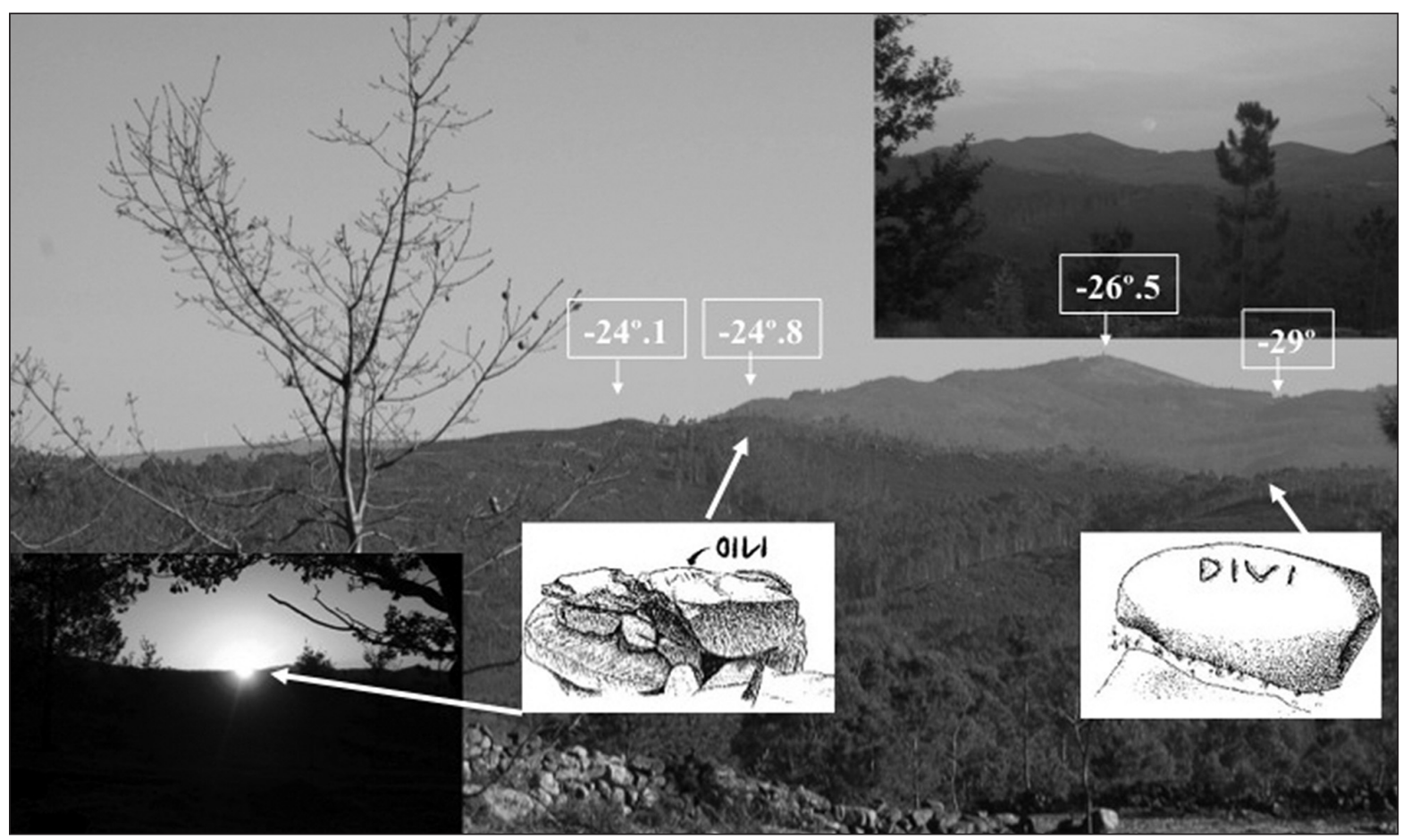

Fig. 3. SE horizon from Laxe dos Carballos. The two small inset pictures indicate sunrise at the WS (lower left), and full moonrise at the SML of July 2006 (upper right). The drawings indicate the shape and location of the two DIVI inscriptions. The numbers indicate the astronomical declination for different points in the horizon.

3 This is not surprising, given the frequent connection between deer and concentric circles in Galician rock art. However, this particular setting appears only in 25\% of the cases, as noted by Åsa Fredell (2006.129-130), while in our sample it appears in three out of four cases.

4 Normally called the lunar standstill, we prefer the nomenclature of lunastice, as opposed to the also common name lunistice. First, the term lunastice is a parallel to the solar solstice, meaning solar standstill. Second, the Latin word Luna declines to luna-stitium, or lunastice. 
right antler. Starting at the farthest to the right and counting three times (right-left-right), we obtain $12+(12+$ 1) $+12=37$, which is the number of lunar months in three solar years, as explained above (Fig. 4). The isolated stroke in the upper part of the left antler may represent the intercalary month.

The carved panel at Laxe das Cruces (Ponte Caldelas; Fig. 2b) is $20 \mathrm{~km}$ to the south of Campo Lameiro. The large deer in this panel complies with all of the characteristics found in the deer of Laxe dos Carballos, so this is not a 'unicum'. There is a distant horizon to the southeast, as in Laxe dos Carballos where the moonrise at the SML occurs at a notch in the intersection of this distant horizon with a closer mountain (Fig. 5;

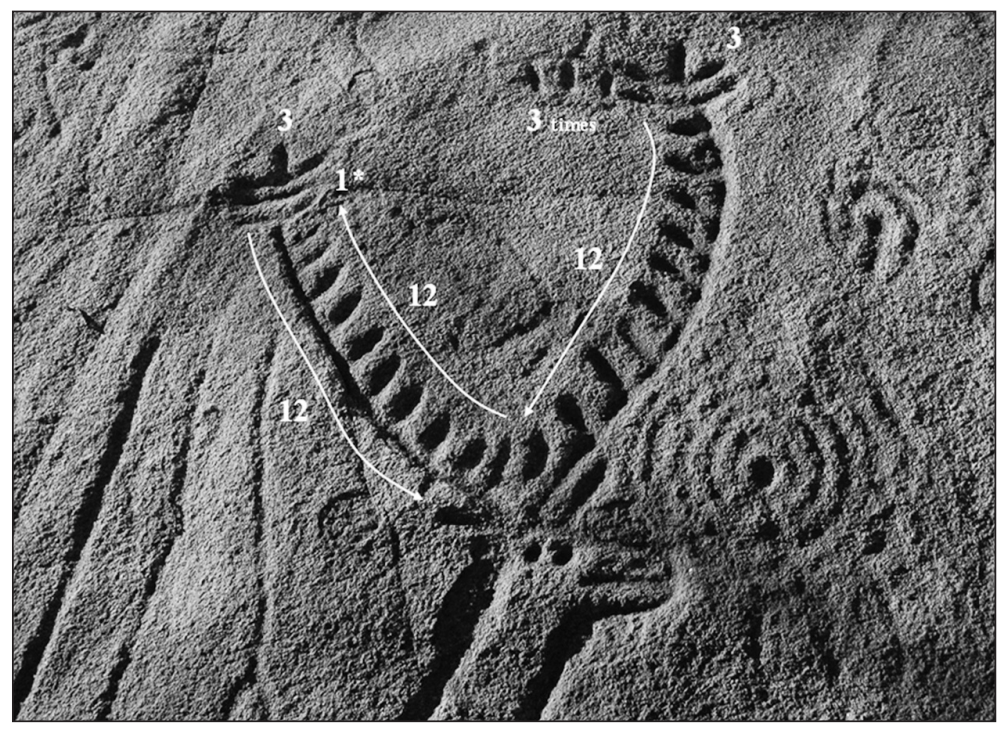

Fig. 4. The calendrical marks of the deer of Laxe dos Carballos. Each antler has 12 tines, with an extra stroke marked in the left one. The two antlers end in a three-tine mark. Finally, there are three additional strokes next to the right antler. For more on the calendrical details, see text.
Tab. 1). Moreover, this deer also presents three strokes next to the right antler, again perhaps indicating a counting procedure. The tines of the antlers could be counted in the following way: $(11+2)+$ $12+12=37$, again giving the number of lunar months in three solar years. Admittedly, this way of counting is subjective, but the similarities with the deer in Laxe dos Carballos, especially the horizon observations, are remarkable and seem to back up each other.

Our third panel in Rotea de Mendo is situated to the east of the Campo Lameiro area (Fig. 2c). Large eucalyptus trees surround this panel at present, which prevented us from observing the horizon. We were able to reconstruct the visibility with a 3D GIS model of the area (Fig. 6), although the horizon reconstruction is approximate, as we lack the fine detail, the most distant horizon opens to the southeast, with interesting possible landmarks towards SML and WS happening at the intersection of distant and closer lines of horizon.

Other smaller deer and circular motifs, including a large circle to its right, surround this great deer. It faces right and fulfils eight of the characteristics indicated. The only exception is the absence of the three strokes beside the right antler. The deer has two large symmetrical antlers, each with 13 tines, although the left antler seems to have an extra feature with another 4 tines. The sum of $13+13+4=$ 30 once again yields a lunar number.
Our fourth great deer in this region is located at Campo de Cuñas (Ponte Caldelas; Fig. 2.d). However, apart from its size, none of the characteristics so far analysed apply to this deer, not even the horizon, as it is located in a place with a rather close horizon in all directions. As a result, we would consider this as merely a large representation of a deer. While this deer and most of the normal size deer in the Galician carvings have a mean of seven tines, the previous large deer are not 'naturalistic' representations: deer in nature usually have an average of seven tines on each antler. In nature, eleven or tentine deer are found in exceptional cases.

These carvings present a particular example of how time reckoning and landscape may be intimately related: the choice of carving site was intentional, favouring places with a clear view of the south-eastern horizon, where it is possible to observe important moments in the movements of the sun and moon at particularly interesting points. Also, the carvings might present, in an intuitive way, how the people who carved them may have tried to combine in the simplest possible way the cycles of the sun and moon (in a lunisolar cycle of three years).

In summary, the carved great deer with 'abnormal' antlers are animals that are 'good for thinking' (Sperber 1975), in this case in relation to the apprehension of astral events with the panel's topographic location, and with a symbolism related to the same order of facts: the possible knowledge of simple luni- 


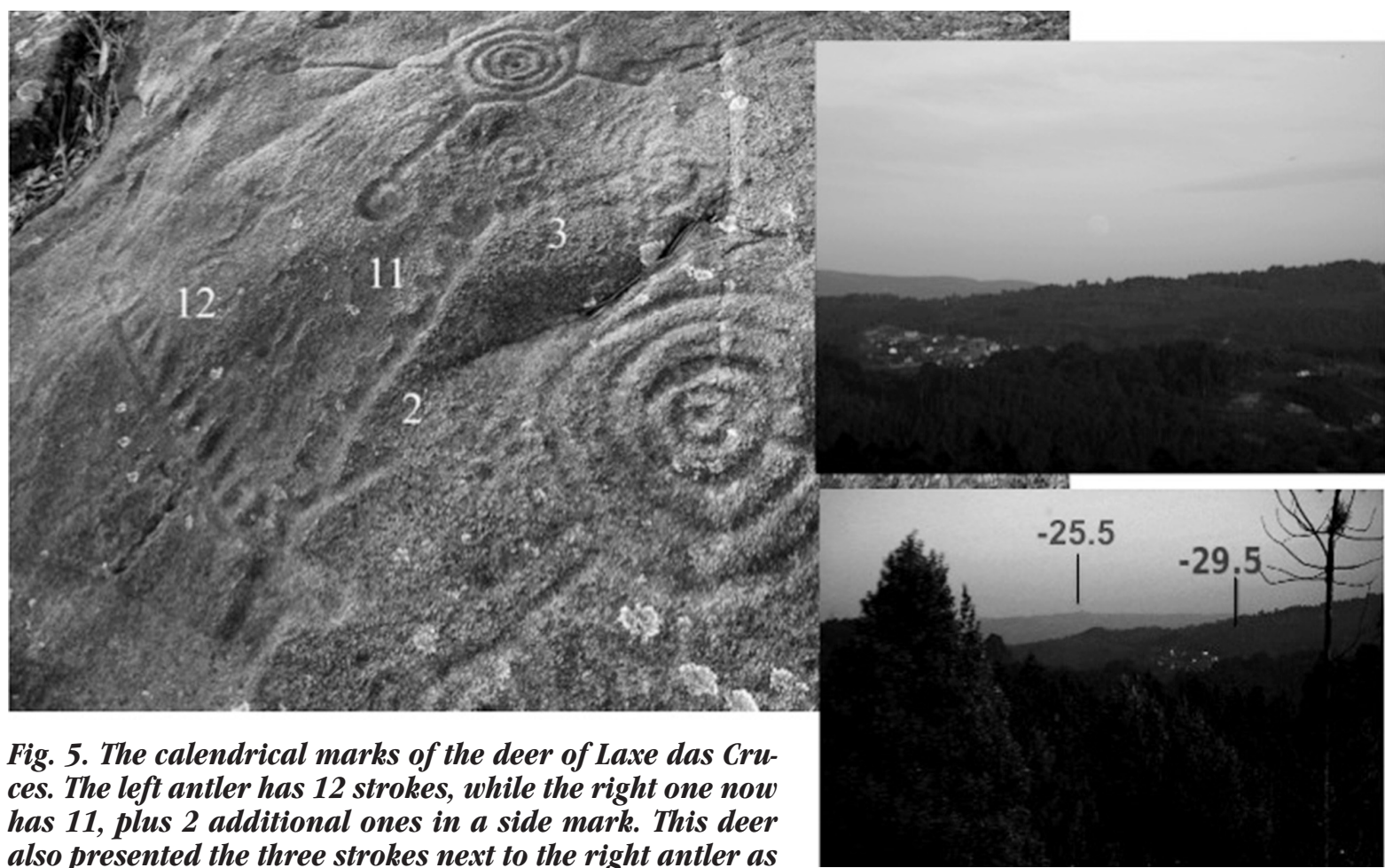
also presented the three strokes next to the right antler as the Laxe dos Carballos one. The right pictures show the southeast horizon observed from Laxe das Cruces (bottom) and the SML moonrise for July 2006. The numbers indicate the astronomical declination for different points in the horizon. For further details, see text.

solar cycles. In particular, the panels at Laxe dos Carballos and Laxe das Cruces with the three isolated strokes may indicate a three-year cycle, when nature's clock could be gauged in a simple but still particular and important way through the observation of particular astronomical events.

\section{Panoias: Latin texts and indigenous timekeep- ing}

The rock sanctuary of Panoias (Vila Real, northern Portugal) has been known since the eighteenth century; it consists of a series of excavated rocks with different structures and up to five inscriptions (see Alföldy 1997, for all of the archaeological and epigraphic issues), one of which is now destroyed, and another in bilingual Greek-Latin, concentrated next to rock no. 1. In formal terms, it has wellknown parallels in North Portugal (González-Ruibal 20062007.562-567; Santos 2010) and Galicia (García Quintela, Santos Estévez 2008.97142), as they are based on large rocky surfaces subjected to an intentional harmonically distributed work in the nastice). form of holes, reliefs, decorations, etc. The inscriptions clearly reveal the culturally mixed nature of the Panoias sanctuary, as they make equal mention of local divinities, the standard Latin divine expressions diis deabusque (two occasions), and a mystic cult dating to the second or third century $\mathrm{AD}$, with careful observations of superimposed carvings revealing different stages of production (Santos 2010).

We were able to take a number of measurements of the rocks conventionally numbered as 2 and 3 , as other rock inscriptions and carvings in the settlement did not offer measurable patterns. The excavated area around rock number 2 is interpreted as

\begin{tabular}{|c|c|c|c|c|c|c|}
\hline \multicolumn{2}{|l|}{ Site } & \multirow{2}{*}{$\frac{A\left({ }^{\circ}\right)}{126^{1 / 2}}$} & \multirow{2}{*}{$\frac{h\left({ }^{\circ}\right)}{2.5}$} & \multirow{2}{*}{$\frac{\varphi}{42^{\circ} 32^{\prime}}$} & \multirow{2}{*}{$\frac{\delta\left({ }^{\circ}\right) \pm 1^{\circ}}{-24.1}$} & \multirow{2}{*}{$\frac{\text { Astronomical Event }}{\text { WSS }\left(-24^{\circ}\right)}$} \\
\hline Laxe dos & DIVI N & & & & & \\
\hline Carballos & DIVIS & $134^{1 / 2}$ & 3.0 & $42^{\circ} 32^{\prime}$ & -29.0 & $\operatorname{SML}\left(-29^{\circ}\right)$ \\
\hline Rotea de & North & 125 & 1.5 & $42^{\circ} 32^{\prime}$ & -23.9 & $\operatorname{WSS}\left(-24^{\circ}\right)$ \\
\hline Mendo* & South & 132 & 1.5 & $42^{\circ} 32^{\prime}$ & -28.4 & $\operatorname{SML}\left(-29^{\circ}\right)$ \\
\hline \multicolumn{2}{|c|}{ Laxe das Cruces } & 133 & 1.0 & $42^{\circ} 24^{\prime}$ & -29.5 & $\operatorname{SML}\left(-29^{\circ}\right)$ \\
\hline
\end{tabular}

Tab. 1. Archaeoastronomical observations in Galicia. Columns 1 show the observation point, 2 the azimuth $A, 3$ the height of the horizon $h, 4$ the latitude of the site, 5 the given declination and 6 the corresponding astronomical event (WSS = winter solstice sunrise; SML = southern major lu- 


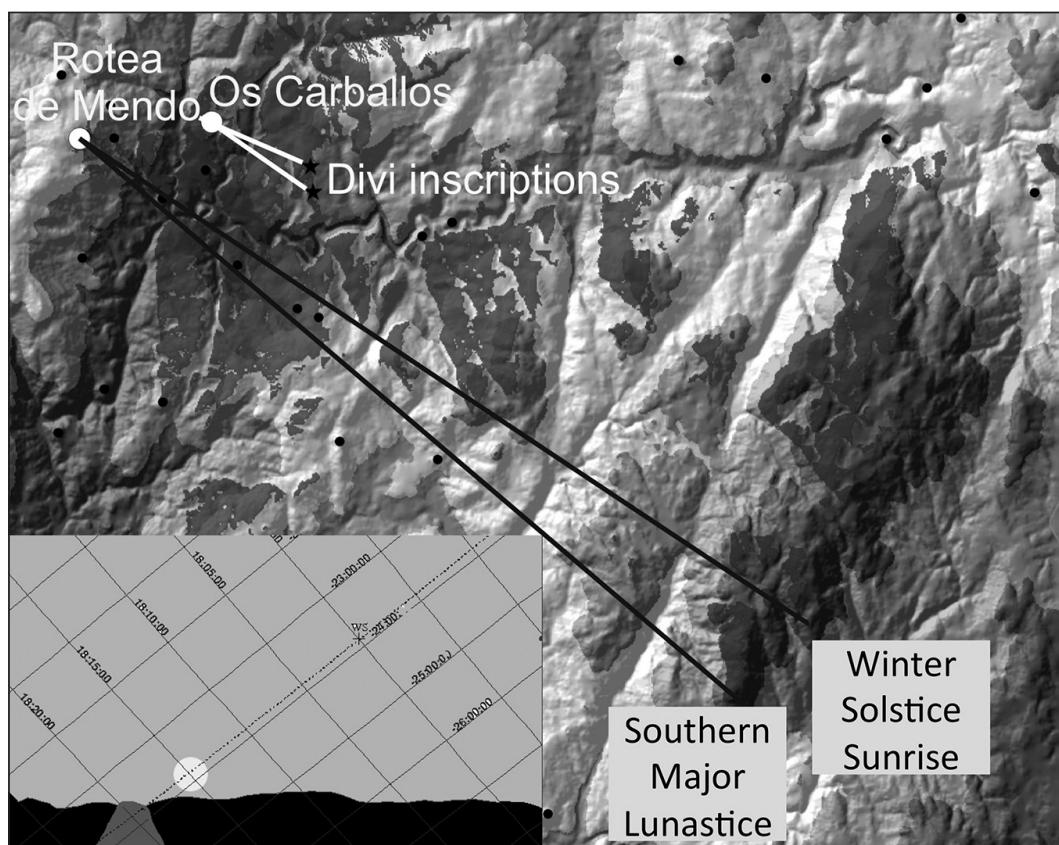

Fig. 6. Visibility of the eastern part of the landscape seen from the deer of Rotea de Mendo with an indication of the lines for WS and SML. Inset: reconstruction of the SE horizon seen from the engraved panel; the grey shaded area corresponds to a closer feature seen in the background of more distant hills.

a platform for the foundations of a building, such as those mentioned in the inscriptions (aedes, inscription no. 2), whose gate, also excavated on the rock, was facing moonrise at SML and may suggest a lunar association for the corresponding shrine5. Rock 3 is a complicated structure that includes a number of deeply carved basins. There is no gate in this cluster of ritual elements; however, most of the carved and excavated structures cluster in the eastern part of the rock, so we considered this as the most probable for our measurements. Thus, an overall orientation of the main elements of the platform can be established at $124.25^{\circ}$, a suggestive figure, as it is close to the minimum declination of the sun at the winter solstice (Fig. 7; Tab. 2).

It is relevant to note that both measurements can be easily related to the three occasions (one reconstructed) when the word templum appears in the local inscriptions (no. 1: diis [deabusque templi] huius ...; no. 2: Diis Seve[r]is in hoc templo lo[ca]t i]s ...; no. 3: omnibusque numinibus et Lapitearum cum hoc templo sacravit ...). We legend see Table 1. must recall that the function of the Roman augur was to establish a templum in caelo (Cipriano 1983; Magdelain 1990) and thus we can infer the conscious use of orientations looking towards the horizon. Far away from Rome, the word can easily be used to integrate or to understand more romano, the orientations mentioned above, or others we cannot recognise.

These observations suggest a different materialisation, the result of a different local history, from the case studied in Campo Lameiro: a relationship between the 'monument' (the great deer of Laxe dos Carballos or the platform/basins in Panoias) and the inscriptions connected with the sunrise at the winter solstice and moonrise at the southern major lunastice. The horizon at this site does not offer a particular feature in those directions, but these are signified by the orientations of the different elements.

\section{Celtiberia: Numantia and Peñalba de Villa- star, a cultural crossroads and the organisa- tion of space/time}

The Peñalba de Villastar sanctuary is located some $10 \mathrm{~km}$ south of Teruel (Spain), and occupies a cliff at the top of a plateau flanked to the east by the River Turia. It has been studied since the early twentieth century due to the accumulation of rock inscriptions in Celtiberian and Latin languages and, to a lesser extent, due to the carvings etched in the soft limestone. Francisco Beltrán et alii (2005.938-939; Marco, Alfayé 2008) describe a set of newly discovered Latin inscriptions called the 'Great Panel'.

\begin{tabular}{|lcccrr|}
\hline Site & $\mathrm{A}\left({ }^{\circ}\right)$ & $\mathrm{h}\left({ }^{\circ}\right)$ & $\varphi$ & $\delta\left(^{\circ}\right) \pm 1^{\circ}$ & Astronomical Event \\
\hline Rock \#2 & $132^{1} / 4$ & 1 & $41^{\circ} 17^{\prime}$ & -29.8 & SML $\left(-29^{\circ}\right)$ \\
\hline Rock \#3 & $124^{1} / 4$ & 1 & $41^{\circ} 17^{\prime}$ & -24.5 & WSS $\left(-24^{\circ}\right)$ \\
\hline
\end{tabular}

Tab. 2. Archaeoastronomical observations at Panoias. For

\footnotetext{
5 The second Christian Council of Braga, a city near Panoias, held in 572, strictly forbade Christians to observe some pagan traditions such as observare et colere elementa at lunam aut stellarum cursum. Braga Council II, 72, (Vives 1963.103; similarly, at the XII Council of Toledo in 681, Vives 1963.398). While it is impossible to strictly connect the observations from Panoias (and elsewhere in northwest Iberia) with these Christian prohibitions, they do reveal the interest in and opportunity to use archaeoastronomical observations in order to try and understand what really lay behind the previously mentioned pagan astral observations.
} 


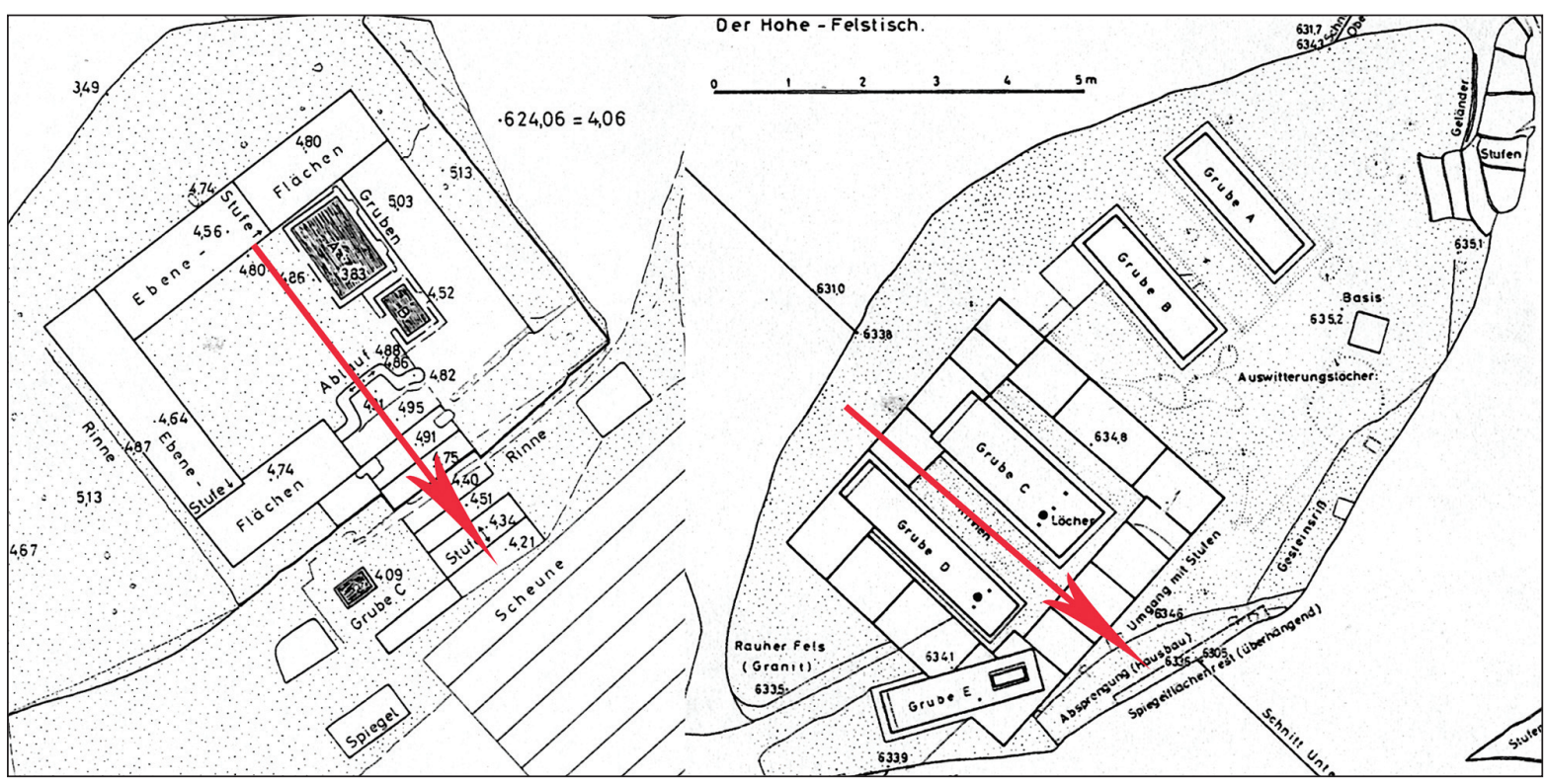

Fig. 7. Archaeoastronomical orientations of the carved rocks of Panoias. Left rock 2, right rock 3. The arrows indicate the measured directions considered in the text (adapted from Alföldy 1997).

There, a local god, Cordonus, is identified by the Latin epithet Cornutus, which is strongly suggestive of the god Cernunnos, well known in ancient Gaul. Another Latin text from the same Great Panel mentions actions related to the winter solstice and a feast during the last days of April (García Quintela, González García 2010).

The motifs carved in the limestone cliff that could be dated to the Iron Age (Fig. 8), are grouped in the areas of the rocky wall where the inscriptions are also located, leaving empty areas between. As shown in figure 8 , these parts of the cliff systematically face southeast in the broad sense. Of course, we do not claim that the perpendicular to the surface they were carved on points precisely to the winter solstice sunrise or the southern major lunastice. The panels face in the general southeasterly direction. This is the general orientation of the cliff, but particular areas of the cliff with different orientations lack 'ancient' inscriptions and carvings. The inscriptions appear only in areas that are roughly face southeast. It must be stressed that nature is not intentionally oriented, but the Turia valley in this area has several other plateaus with cliffs which could have been used.

Inspecting the eastern horizon from these sites, we verified that the carvings face the point where the sun rises at the winter solstice through a notch on the distant horizon. Moonrise at the SML is also relevant, as it would occur on top of one of the farthest observable mountains in that part of the horizon. Finally, the so-called 'Great Panel' is located in an area with difficult access, where the cliff twists, making it possible to observe only an important landmark on the horizon, a peak where sunrise could occur close to October 29th (see Fig. 8, the peak marked with $-12.6^{\circ}$ of declination).

It is interesting to stress that the reference to the winter solstice on the 'Great Panel' inscription apparently coincides with the archaeoastronomical observations on the horizon. Also, the date at the end of April forms a pair with the eastern point, where sunrise occurs on October 29th: It shows that the sanctuary was facing sunrise in the dark part of the traditional Celtic year (conventionally between November $1^{\text {st }}$ and May 1 st, a period that would include the SML during the years of the lunar cycle when this actually happens) ${ }^{6}$.

These observations share some similarities with those mentioned for Campo Lameiro (in García Quintela, González-García 2010 we stressed the differences between the two places, as it is not our intention for the similarities to be so general) and A Ferradura (García Quintela, Santos Estévez 2008.231-295), because we may see the 'natural' observation of par-

6 Here it is interesting to note one of the precepts of the first Christian Council of Zaragoza, held 380: between 17th December and

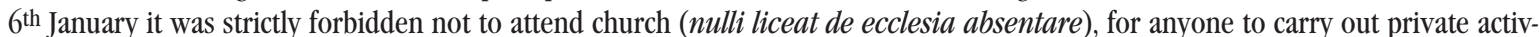
ities, or to fall victim to pagan practices such as travelling to the mountains or walking barefoot (nec montes petere, nec nudis pedibus incedere) Zaragoza Council I, 4, (Vives 1963.17). 


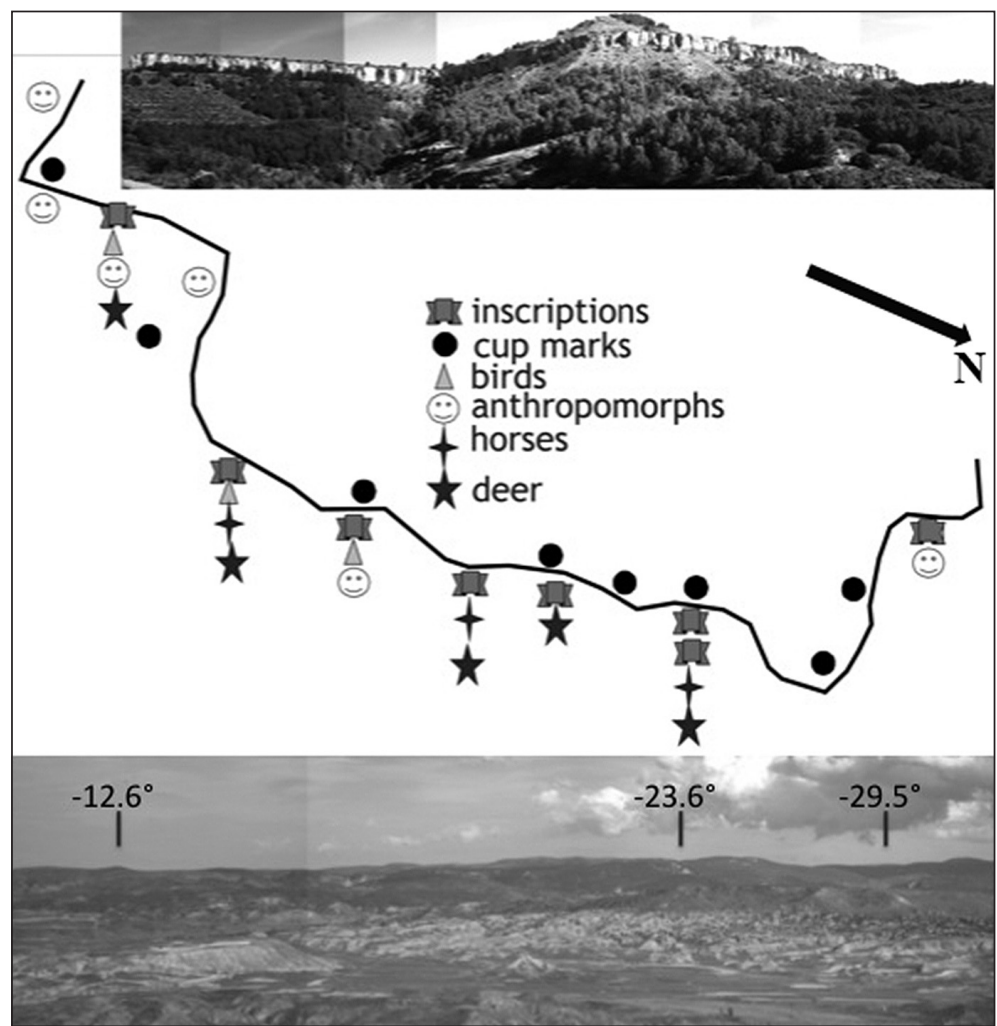

Fig. 8. The rock art sanctuary of Peñalba de Villastar. Above, a general view of the rock wall as seen from the valley from the southeast; in the centre, the location of the 'old' carvings, sharing their position with the inscriptions. The Great Panel is located in the far right inscription symbol; below, the southeastern horizon from Penalba with the relevant points in relation to astronomical events. ramic supports, mainly associated with solar or lunar symbolism. We could also mention a decorated plaque (usually interpreted as a 'breastplate') that may be an iconographic complement to the observations in Peñalba de Villastar.

The plaque (Fig. 9) was found during the excavation of the Numantia necropolis (Jimeno et al. 2004). Similar pieces have been found in other Celtiberian necropolises, especially in the Arcobriga collection (Lorrio, Sánchez de Prado 2007; Lorrio et al. 2005). The plaque was part of tomb no. 68 , which due to the number of objects (17) is one of the richest at this site. It is important to stress the mutual exclusion of arms and decorated plaques and that these appear in the tombs of both women and men (Jimeno et al. 2004.208, 341, 382). The piece is described thus: "The plaque in tomb 68 is composed of three rectangular sheets $(6.7 \times 5.1 \mathrm{~cm})$, joined at their smaller edges by two rings; two trapezoidal plaques ending in astral or lunar discs hang from the third

ticular moments of the solar and lunar cycles (solstices and lunastices). However, it might include other variables not observed at Campo Lameiro such as mid-season festivals. Also, they convey what we have already referred to: the relation between the 'monument' (the whole sanctuary in this case), the inscriptions (with explicit references to particular dates in this case) and the observations on the horizon.

To complete the case, it should be noted that numerous deer are depicted among the carved motifs in Peñalba, although none has the characteristics of the great deer in Galicia. Nevertheless, the deer is commonly found in Celtiberian art on metallic or ce-

\begin{tabular}{|lccccr|}
\hline \multicolumn{7}{c|}{ PEÑALBA DE VILLASTAR } \\
\hline Site & $\mathrm{A}\left({ }^{\circ}\right)$ & $\mathrm{h}\left({ }^{\circ}\right)$ & $\varphi$ & $\delta\left({ }^{\circ}\right) \pm 1^{\circ}$ & Astronomical Event \\
\hline Horizon notch & $1223 / 4$ & 0.75 & $40^{\circ} 15^{\prime}$ & -23.6 & WSS $\left(-24^{\circ}\right)$ \\
\hline Distant Mountain & 132 & 1 & $40^{\circ} 15^{\prime}$ & -29.5 & SML $\left(-29^{\circ}\right)$ \\
\hline Great Panel & $107^{1} / 4$ & 0.25 & $40^{\circ} 15^{\prime}$ & -13.2 & $\begin{array}{r}\text { Sunrise Feb 13/ } \\
\text { Oct 29 }(\sim 200 B C)\end{array}$ \\
\hline
\end{tabular}

Tab. 3. Archaeoastronomical observations at Peñalba de Villastar. For legend see Table 1. or bottom plaque. A staircase-like frieze frames all the articulated elements. The three plaques bear the same motif: a schematic horse with a flat muzzle and standing, with four flat legs and horsehairs simulated with thin lines like a crest. A small sheet in the upper part decorated with a concentric circle and drilled with a needle allowed it to be hung." (Jimeno et al. 2004.210).

As a result, the plaque reproduces a count similar to that found in the deer of Laxe dos Carballos and Laxe das Cruces, this time replacing the deer with a horse, a fact well known in Celtiberia (Lorrio, Sánchez de Prado 2007.151): counting the number of horsehairs of the three horses there are 37 with 12 on the top and bottom horses, respectively, and 13 on the central horse. It is true that the calendric significance of this number is speculative, but the astral meaning of this series of representations is commonly accepted (Jimeno et al. 2004. 205-210). 
Once again, we are aware of the differences: here we are dealing with metal, not stone, and the animal is a horse, not a deer, although the connection between both species and solar symbolism was a constant feature of the Bronze Age (Briard 1987; Kristiansen, Larsson 2006.355-407; Bradley 2006; Garrido, Muñoz 2000), and an apparent substitution of the deer by the horse in artistic remains through time has been postulated (Lorrio, Sánchez de Prado 2007.151-153). In any case, a more detailed study would be necessary, considering the same series found in this plaque in the context of other similar plaques.

In summary, in the three cases explored we have a 'monument' (rock carvings, rocky sanctuaries, or both) with observations on the horizon and possible calendric information (either explicit in Peñalba, or suggested by horizon features and perhaps 'abnormal' antlers).

\section{Diachrony, landscape and structure}

We will now incorporate a diachronic process. The astronomical events we have referred to, the southernmost rise of the sun or moon, were not affected by secular changes, and would have changed by less than $1^{\circ}$ due to the variation in the obliquity of the ecliptic, (less than the precision claimed by our measurements) throughout the period of the first and second Iron Ages for the area (from nearly $900 \mathrm{BC}$ to the change of era). Unfortunately, a diachronic analysis is possible only if we apply the knowledge derived from an intensive archaeological, geomorphologic and palaeo-environmental study in Campo Lameiro, but we lack such information for the other areas studied here. Furthermore, in Campo Lameiro, we depend largely on the results of the Laxe dos Carballos excavation (Santos Estévez 2008a).

We will use the relative stratigraphic study carried out on the great deer of Laxe dos Carballos by Åsa Fredell (2006) (Fig. 10), noting that it is a working hypothesis in which we have combined Fredell's proposal with the archaeoastronomical observations in that area. Such a proposal indicates the existence of several phases in the evolution of the carvings in Laxe dos Carballos where we might see the introduction of the astronomical elements investigated above.

(1) There is a clear difference in depth between the great deer and the surrounding carved motifs (Fig. 10 - top left panel). There are two explanations:

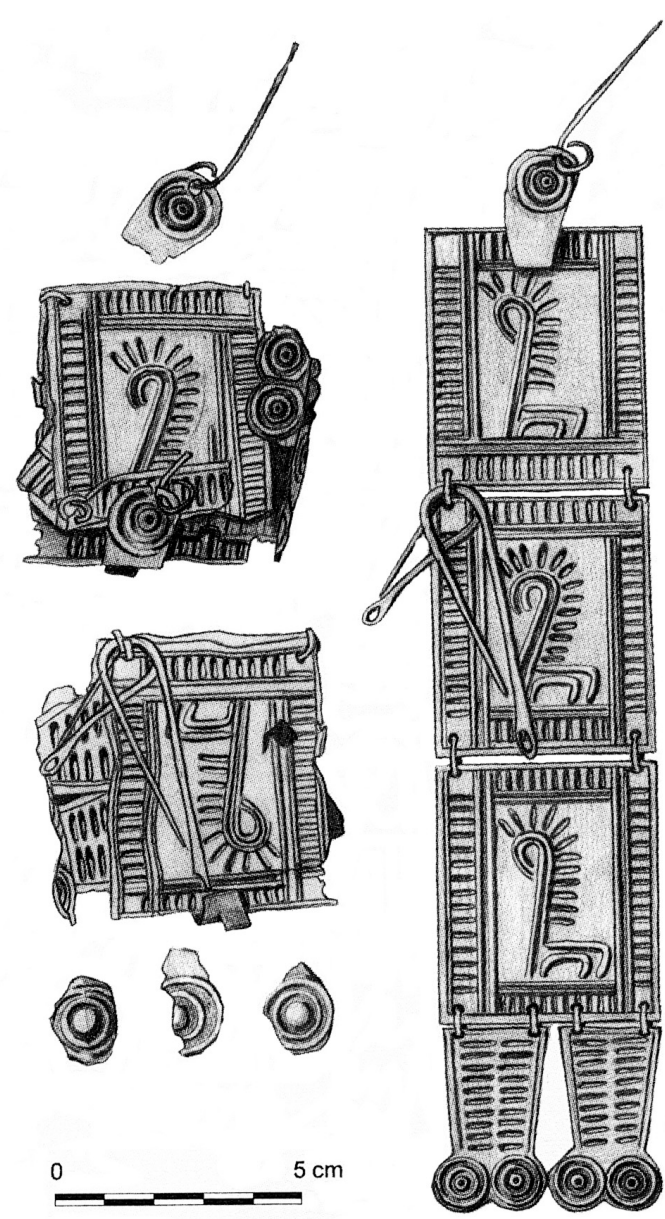

Fig. 9. Decorated bronze plaque from Numantia (after Jimeno 2004).

either the more superficial carvings were subject to more prolonged erosion, or they were carved with 'softer' tools. Either reason, or a combination of both, would mean that the great deer is more recent than the others, according to Fredell, who dates the deer to the end of the Bronze Age $(c .800 \mathrm{BC}$; Fig. 10 - bottom left panel), although we do not know if this date is relevant for the astronomical observations.

(2) We take Fredell's phases two and three together (Fig. 10 - top right panel). These phases have been dated through the adjacent stratigraphy to the first Iron Age, and continue until the change of era with the working calendrical count. This count relates the cycles of the sun and moon, and so it is probable that the two astronomical events on the horizon were recognised at this stage.

(3) According to Fredell, the last part to have been carved is the groove through the deer's neck (Fig. 10 - top right panel). This could be a necklace or, we suggest, a torque, considering the omnipresence of this attribute in Cernunnos iconography (Bober 
1951). The DIVI inscriptions on the first line of the horizon are also dated to the beginning of the era, highlighting the relationship between Laxe dos Carballos and the southeastern horizon.

(4) Finally, it is possible to identify the chronologiccultural moment of the introduction of Christianity, according to an already identified model (Ayán 2005; García Quintela 2006): the patron saints of the hamlets of Praderrei (Saint Blaise, February 3 rd) and Paredes (Saint Anthony, January 17th) next to Laxe dos Carballos are celebrated close to the Celtic mid-season feast of winter. Also, the Fentáns slope (the one close to the DIVI inscriptions) is Christianised by the saints Justus and Pastor, whose feast day is on August $6^{\text {th }}$, close to the Celtic mid-summer feast. These saints are all palaeo-Christian, and therefore it could be justified to date their introduction in late Antiquity.

Thus we see that the elements associated with a calendric system in this carved panel could be connected with a cultural horizon from the first Iron Age, which, as mentioned above, is certainly indo-European and perhaps Celtic in this region of Galicia.

Turning away from Galicia, the cases in Panoias and Peñalba de Villastar appear to be more firmly embedded due to the local inscriptions which explicitly mention events, dates or gods that lend substantial support to our interpretation, but which also present chronological problems. Firstly, there are no excavations or substantial geomorphologic studies to make a geological and palaeoenvironmental his-
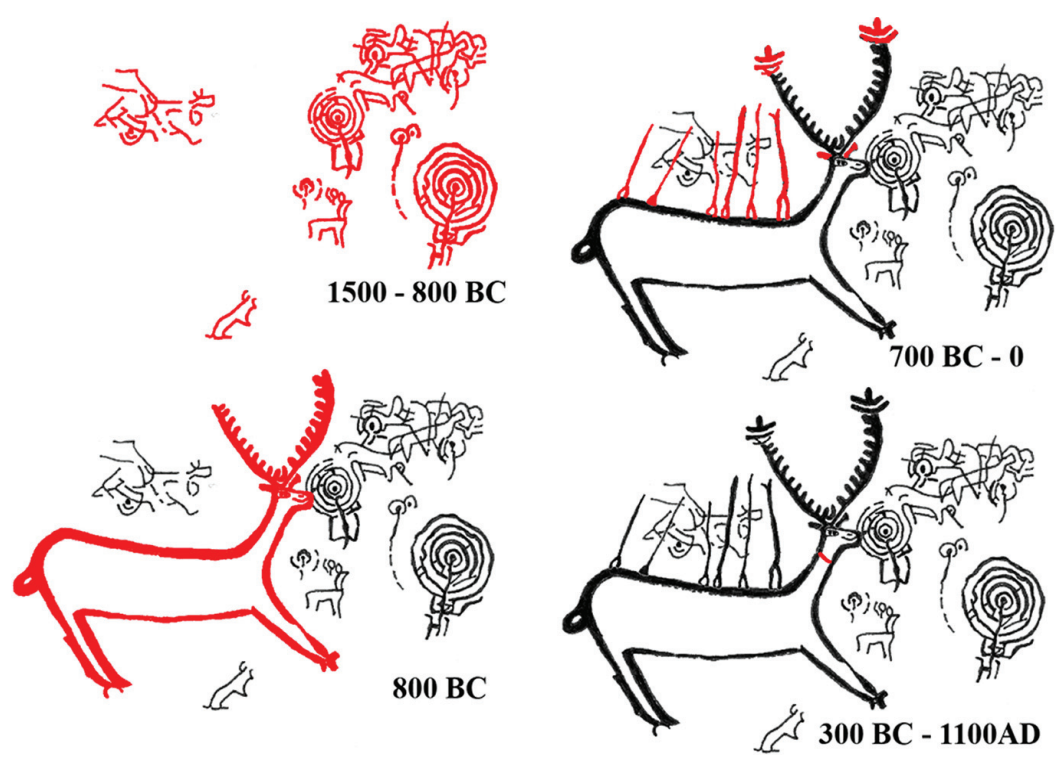

Fig. 10. Fredell's stratigraphic-chronological proposal for the Laxe dos Carballos deer. tory of both sites possible. Under these conditions, the chronology depends on the correct interpretation of the given data.

In Panoias, fortunately, the inscriptions explicitly refer to a previously existing religious cult of native gods and the implementation of a new religious strata and meaning by the hand of notable and cultivated Roman from the Imperial Age. Also, the detailed examination of the carved pits made by Maria J. Santos reveals traces of overlapping and, therefore, longlasting, but still imprecise, use (Santos 2010).

Peñalba is a more difficult case, as people from all periods left signs of their presence on the soft limestone of the cliff. The problem is to establish when the religious aspects make it possible to define the site as a 'sanctuary'. The dominant epigraphic research limits the temporal gap to the history of writing in this specific place - starting in Celtiberian times - the question being whether some carvings are earlier and have a religious meaning. In any case, it is interesting that, according to the inscriptions in the Great Panel, the site was already recognised by Roman times as a sacred area where ritual had to be performed on specific dates. Finally, the plaque from Numantia is clearly from Celtiberian times, a few centuries $\mathrm{BC}$.

This possible Celtic milieu points to the active cultural role of priests, known as druids in other Celtic areas; known from Classical sources as physiologoi, they were knowledgeable on heavenly bodies (supra, and see García Quintela 1999 and Marco Simón 1994, for the druids in Spain). Apparently, Celtic ideology was dominated by a dual conception expressed in particular in their organisation of time reckoning, beginning with the "dark side", meaning night before day or winter before summer (Caesar De Bello Gallico VI, 18, 2; Duval, Pinault 1986.404405). Finally, a number of investigations have indicated the persistence of Celtic elements in Christian traditions (Guibert de la Vaissière 2003; Laurent 1995; McCluskey 1989; MacNeill 1962).

However, a chronological interpretation of the different ele- 
ments carved in each panel or site is not the same as interpreting the panel itself or, even less so, a number of panels in a certain area, or the sites as a whole. In any case, one of the peculiarities of our analysis is that it uses archaeoastronomical observation as the common factor that connects different parts of the landscape. This structural understanding allows us to elaborate some ideas on the methodology and relations between space and time.

\section{Space/time continuum and sacred landscape}

We have used the archaeological data to propose an iconographic analysis which considers the different sites as the result of an on-going process during a prolonged period of time. This proposal makes it possible to incorporate cultural elements from the Iron Age into the process of interpreting the motif.

As an astronomical matter, we have proposed a possible case for one or several lunisolar calendars, whose best-known example in the Celtic cultural tradition would be the Coligny calendar, but which need not be the only materialisation of knowledge of the skies among peoples of Celtic cultural traditions.

Finally, the combination of landscape archaeology and the history of religion allows us to propose an interpretation. This proposal consists of achieving a global comprehension of the carved panels in a given area by examining their possible connections. Archaeoastronomical observations make it necessary to carry out this type of analysis, as they give added value to a number of other elements (the nature of the rock, configuration of the landscape, habitat distribution, panel placement, motifs used, etc.).

It is interesting to note that the cases studied so far (the carved deer from southern Galicia, Panoias, Peñalba and the plaque from Numantia) could be considered as structural variables materialised in different ways in each area according to specific historical constraints. According to these facts, shared elements such as time reckoning through lunar phases and festivals, particularly solar dates, may have led people to try and find ways to coordinate both cycles, first through practical observations, such as those which could have been performed in the $\mathrm{Ga}$ lician 'Great Deer' and finally through a 'model' calendar, such as the three-year cycle calendar, the 18.6 or 19 year cycle, or the five-year Coligny calendar. It is necessary to emphasise that it is not our intention for the observations made at these different sites to be considered as the direct precedents of the Coligny calendar, but rather that this framework could have been in place in different Celtic areas with different results. Table 4 may help to elucidate this line of thought.

We use the term 'observation point' or 'back sight' to refer to the spot from where the viewer may look towards the horizon. It may be in itself a naturally oriented site (towards the southeast in most cases), or artificial (Panoias). Next, we consider the 'horizon' where the 'landmarks' or 'foresights' make it possible to situate the astronomical events, which were essentially two: the winter solstice sunrise (WSS) or the southern major lunastice (SML); although in Panoias, the fact that the 'back sight' is artificially oriented makes it possible to dispense with landmarks on the horizon?

The 'texts' share the space with the rock carvings, and together, they either construct the 'monument', or make it possible to select the 'observation point', or indicate relevant points on the horizon. Also, in all the recorded cases, the 'texts' contain mentions or allusions of a religious kind.

It is clear that we are dealing with areas that were culturally constructed and 'thought', which are the properties of a 'landscape'. The accumulated materials are footprints through which it is possible to identify the key cultural elements in this 'landscape'. These footprints are always a combination of natural elements, natural/artificial elements (when a natural element contains an anthropic action) and purely artificial elements (such as the inscriptions).

On a global scale, the sites studied provide a consistent way of understanding the relationship between space and time. This is due to a very fundamental aspect: the reversibility of space and time for an observer at a given spot. The rising and setting of the main celestial bodies will coincide year after year

\footnotetext{
7 This is a complex issue. The Latin rule to establish a templum implies that the augur sets some references on the horizon, which may be a perishable element, such as a tree (Varro, Lingua Latina 7, 8-9). The Celtic term nemeton (found in other sites in Hispania) would also fit this consideration and its meaning, 'sacred place' (Lambert 2008.140), perfectly fits our requirements. In pre-Columbian Mexico the so-called 'Teotihuacan markers' are identified as key elements in the astronomical relations of certain monuments (Iwaniszewski 2006.151-153). We could never know which perishable elements were used in each case, and it is extremely difficult to discern a mark with an astronomical meaning without a relevant study in its context.
} 


\begin{tabular}{|c|c|c|c|c|c|c|}
\hline $\begin{array}{l}\text { Observation } \\
\text { point }\end{array}$ & Horizon & $\begin{array}{c}\text { Archaeoastronomical } \\
\text { observations }\end{array}$ & $\begin{array}{l}\text { Archaeological } \\
\text { indications }\end{array}$ & $\begin{array}{l}\text { Religious } \\
\text { indications }\end{array}$ & $\begin{array}{l}\text { Carved } \\
\text { deer }\end{array}$ & $\begin{array}{c}3 / 18.6 \\
\text { Year Cycle }\end{array}$ \\
\hline \multicolumn{7}{|c|}{ GALICIA } \\
\hline $\begin{array}{l}\text { Os Carballos. } \\
\text { Looking SE }\end{array}$ & Landmarks & WSS / SML & \begin{tabular}{|c|} 
Monumentaliza- \\
tion of landmarks
\end{tabular} & DIVI / DIVI & Yes & Yes/Yes \\
\hline $\begin{array}{l}\text { Laxe das Cruces. } \\
\text { Looking SE }\end{array}$ & Landmarks & WSS / SML & & & Yes & Yes/Yes \\
\hline $\begin{array}{l}\text { Rotea de Mendo. } \\
\text { Looking SE }\end{array}$ & Landmark & WSS / SML & & & Yes & $? /$ Yes \\
\hline \multicolumn{7}{|c|}{ PANOIAS } \\
\hline $\begin{array}{l}\text { Rock } 2 . \\
\text { Aedes SE }\end{array}$ & & WSS & $\begin{array}{c}\text { Rock } 1 \\
\text { "observatory": }\end{array}$ & \begin{tabular}{c|} 
DIIS \\
DEABUSQUE/
\end{tabular} & NO & ?/Yes \\
\hline $\begin{array}{l}\text { Rock } 3 . \\
\text { Basins SE }\end{array}$ & & SML & $\begin{array}{l}\text { indicate } \\
\text { templum }\end{array}$ & $\begin{array}{c}\text { DII SEVERI/ } \\
\text { NUMINA } \\
\text { LAPATIARUM }\end{array}$ & & \\
\hline \multicolumn{7}{|c|}{ PEÑALBA DE VILLASTAR } \\
\hline $\begin{array}{l}\text { General: } \\
\text { Looking SE }\end{array}$ & Landmarks & WSS / SML & In observatory & Local gods & Yes & $? /$ Yes \\
\hline $\begin{array}{l}\text { Great Panel. } \\
\text { Looking SE }\end{array}$ & Landmark & 29th October & $\begin{array}{l}\text { In observatory, } \\
\text { indicate WSS } \\
\text { and end of April }\end{array}$ & God labelled C & ornutus & \\
\hline \multicolumn{7}{|c|}{ NUMANTIA } \\
\hline Plaque & & & | & $\mid$ & Horse & Yes/? \\
\hline
\end{tabular}

Tab. 4. Summary of relevant information.

with certain areas in space. This simple observation may be conferred a special meaning in certain places for a number of reasons, and it is possible that the aggregation of natural features and observations, such as the ones mentioned here, led to more prolonged use in time and their progressive monumentalisation: in our case, this basically means carving motifs and texts in different ways.

The texts examined here underline this equivalence between space and time. The DIVI inscriptions in Campo Lameiro are in positions which, when viewed from Laxe dos Carballos, coincide with the WSS and SML; in Panoias the inscriptions mention an oriented celestial space, templum, whose existence is verified by the astronomical orientation; in Peñalba, the inscriptions offer time indications related in different ways to important landmarks on the horizon. The religious nature of all of these inscriptions puts beyond reasonable doubt the sacred nature of all these spaces, and of the space/time combinations fixed in the landscape.

It is true that the differences between all the sites and artefacts examined here are important. They appear as a result of their inherent morphological and geographical characteristics, and from the different ways in which humans modified the site.
We have also referred to the difficulty of correctly analysing ethnographic texts in order to discover how much was known about astronomical phenomena. So the question remains open, although we can state that, at least, the observations and analyses performed point to the need for further research along these lines.

\section{Conclusions}

A calendrical system is a way of comprehending time and its cycles. The religious and practical issues related to developing a calendar have been highlighted throughout the paper. According to our results, and those stated in the introduction, the different Celtic tribes in the Iberian Peninsula might have comprehended space and time by observations of the solar and lunar cycles, notably the winter solstice sunrise and the moonrise at the southern major lunastice, from certain interesting viewpoints in the landscape. These observation points were therefore 'monumentalised' in different ways (by carving animals in an initial stage and later by engraving inscriptions), including symbolic representations of the events they were interested in, or an inscription with a dedication to a given god or a festival to be carried out at a particular time of the year. 
Therefore, we would like to highlight a series of conclusions:

- Evidence is seen of the use of spatial relations with astronomic events at sites connected in some way with Celtic traditions in the Iberian Peninsula. We highlight the prominence of the winter solstice sunrise and the southern major lunastice moonrise.

- This evidence, which reveals an interest in the sun and moon and their observations at important points of their cycles, is also supported by ethnographic and epigraphic information from these sites, and at a later date, in the interdicts of these observations established by Christianity.

- We may speculate about efforts to create a calendar, although this calendar is not known.

- There is some evidence of a possible calendric cycle of 37 months which was used, in the simplest possible way, to adjust the lunisolar cycles at Iron Age sites in Galicia, and in the plaque from Numantia.

- This calendar was not necessarily the same at all of the sites inhabited by speakers of Celtic languages. In other areas with Celtic traditions, similar observa- tions may have led to other proposals, such as the calendar of Coligny.

It will also be necessary to extend the range of our observations, as other rock art sites are known in Galicia, and other cliffs with archaeological remains are known both in Iberian culture and Celtiberian areas (Peñalba is located on the frontier of both areas). Also, Francisco Marco and Simón Alfayé (2008) introduce other sites in the Iberian Peninsula in their study. As a result, it would be interesting to carry out further research in these areas.

$$
\text { ACKNOWLEDGEMENTS }
$$

Silvia Alfayé Villa was our guide in Peñalba de Villastar and Manuel Santos Estévez our guide to the petroglyphs in Galicia. Åsa Fredell, Alberto Lorrio Alvarado, César Parcero Oubiña and Yolanda Seoane Veiga helped us with the images. The discussion with Daniel Gricourt and Dominique Hollard was the key to interpreting Campo Lameiro. Alfredo González Ruibal read the text and helped us to avoid some errors. This work was partially financed by the projects AYA 2004-01010 and AYA 2007-60213, Orientatio ad Sidera I, II and III of the Spanish MICINN. ACGG is a Ramón y Cajal Fellow of the Spanish MINECO.

\section{$\therefore$}

\section{References}

Alföldy G. 1997. Die Mysterien von Panóias (Vila Real, Portugal). Madrider Mitteilungen 38: 176-246.

Alonso Romero F. 1983. Nuevas consideraciones sobre el significado del petroglifo de Laxe das Rodas (Muros, Galicia). Zephyrus 36: 79-91.

Argente J. L., Díaz J. L. and Bescós A. 2001. Tiermes $V$. Carratiermes. Necrópolis celtibérica. Junta de Castilla y León. Valladolid.

Ayán Vila X. M. 2005. Etnoarqueoloxía e microhistoria dunha paisaxe cultural: a parroquia de S. Pedro de Cereixa (Pobra de Brollón, Lugo). Cuadernos de Estudios Gallegos 52: 117-172.

Baquedano I., Escorza C. M. 1998. Alineaciones astronómicas en la necrópolis de la edad del Hierro de La Osera (Ávila, España). Complutum 9: 85-100.

2008. Sacerdotes vettones: el sol y las estrellas. Un mapa estelar en la necrópolis de La Osera. In J. R. Álvarez Sanchís (ed.), Arqueología Vettona. La Meseta Occi- dental en la Edad del Hierro. Comunidad Autónoma de Madrid. Madrid: 311-320.

Belmonte J. A., Hoskin M. 2002. Reflejo del Cosmos: Atlas de Arqueoastronomía del Mediterráneo Antiguo. Equipo Sirius. Madrid.

Beltrán Lloris F., Jordán Cólera C. and Marco Simón F. 2005. Novedades Epigráficas en Peñalba de Villastar (Teruel). Palaeohispanica 5: 911-956.

Bender B. 2002. Time and Landscape. Current Anthropology 43: S103-S112.

Bober Ph. F. 1951. Cernunnos: Origin and Transformation of a Celtic Divinity. American Journal of Archaeo$\log y$ 55(1): 13-51.

Bradley R. 2006. Danish razors and Swedish rocks: Cosmology and the Bronze Age landscape. Antiquity 80: 372389. 
Briard J. 1987. Mythes et symboles de l'Europe préceltique: les religions de l'Âge du Bronze: (2500-800 av. J.C.). Editions Errance. París.

Brunaux J. L. 2006. Les druides. Des philosophes chez les Barbares. Seuil. Paris.

Burenhult N., Levinson S. C. 2008. Language and landscape: a cross-linguistic perspective. Language Sciences 30: $135-150$.

Cipriano P. 1983. Templum. Biblioteca di Ricerche Linguistiche e Filologiche 13. Roma.

Collis J. 2003. The Celts. Origins, Myths, Inventions. Tempus. Stroud.

Criado Boado F. 1989. 'We, the post-megalithic people...' In I. Hodder (ed.), The Meanings of Things. Material Culture and Symbolic Expresión. Routledge. London: 79-89.

Criado Boado F. 1999. Del terreno al espacio. Universidad de Santiago de Compostela. Santiago.

De Bernardo P., García Quintela M. V. 2008. Población trilingüe y divinidades del castro de Lansbriga (NO de España). Madrider Mitteilungen 49: 255-291.

Dupré Raventós X., Ribichini S. and Verger S. (eds.) 2008. Saturnia Tellus. Definizioni dello spazio consacrato in ambiente etrusco, italico, fenicio-punico, iberico e celtico. Consiglio Nazionale delle Ricerche. Ufficio Pubblicazioni. Roma.

Duval P.-M., Pinault G. 1986. Recueil des inscriptions Gauloises (RIG). Vol. III. Les Calendriers (Coligny, Villards d'Heria). Centre National de la Recherche Scientifique editions. Paris.

Fredell Å. 2006. Solhjorten fanns den?: fallstudium av ett galiciskt bildtema och dess relationer till identitet. In R. Barndon, S. M. Innselset, K. K. Kristoffersen and T. K. Lødøen (eds.), Samfunn, symboler og identitet - Festskrift til Gro Mandt på 70-årsdagen. Arkeologisk Institutt. Bergen: 121-133.

García Quintela M. V. 1999. Mitología y Mitos de la Hispania Prerromana III. Akal. Madrid.

2006. Solar Cycle and Landscape: defining a Celtic pattern. In M. V. García Quintela, F. J. González García, F. Criado Boado (eds.), Anthropology of the Indo-European World and Material Culture. Archaeolingua. Budapest: 83-109.

García Quintela M. V., Santos Estévez M. 2008. Santuarios de la Galicia Céltica. Abada. Madrid.

García Quintela M. V., González García A. C. 2010. Campo Lameiro y Peñalba de Villastar: miradas cruzadas sobre lu- gares de culto prerromanos peninsulares y su romanización. In F. Burillo Mozota (ed.), VI Simposio sobre los Celtíberos: Ritos y Mitos. Centro de Estudios Celtibéricos de Segeda. Zaragoza: 113-122.

Garrido Pena R., Muñoz López-Astilleros K. 2000. Visiones Sagradas para los Líderes. Cerámicas campaniformes con decoración simbólica en la Península Ibérica. Complutum 11: $285-300$.

Gaspani A., Cernuti S. 1997. L'Astronomia dei Celti. Keltia Editrice. Aosta.

Gaspani A. 1999. La Cultura di Golasecca. Keltia Editrice. Aosta.

González Ruibal A. 2006-2007. Galaicos: Poder y comunidad en el Noroeste de la Península Ibérica (1200 a.C. -50 d.C.). Brigantium 18-19. A Coruña.

Guibert de la Vaissière V. 2003. Les Quatre fêtes d'ouverture de saison de l'Irlande ancienne. Editions Armeline. Crozon.

Hannah R. 2005. Greek and Roman Calendars: Constructions of Time in the Classical World. Bloomsbury. London.

Hill J. D. 1993. Can we recognise a different European past? A contrastive archaeology of later prehistoric settlements in Southern England. Journal of European Archaeology 1: 57-75.

Ingold T. 1993. The Temporality of the Landscape. World Archaeology 25(2): 152-174.

Iwaniszewski S. 2006. La interpretación arqueoastronómica de la Piedra del Gigante de Orizaba y de la Piedra Semilla (Relieve Solsticial) de Tomacoco. In J. Lull (ed.), Trabajos de Arqueoastronomía. Ejemplos de África, América, Europa y Oceanía. Agrupación Astronómica de La Safor. Valencia:143-159.

Iwaniszewski S. 2009. Por una astronomía cultural renovada. Complutum 20(2): 23-37.

James S. 1993. Exploring the World of the Celts. Thames and Hudson. London.

1999. The Atlantic Celts, ancient people or modern invention? The Bath Press. Avon.

Jimeno Martínez A. et al. 2004. La necrópolis celtibérica de Numantia. Junta de Castilla y León. Valladolid.

Jordán, C. 2007. Celtiberian. In e-Keltoi, Volume 6: The Celts in the Iberian Peninsula: 749-850 http://www4. uwm.edu/celtic/ekeltoi/volumes/vol6/6_17/jordan_6_ 17.pdf 
Jordán C. 2008. Las lenguas celtas de la Península Ibérica. In M. Alberro, C. Jordán, Los Celtas de la Península Ibérica. Toxosoutos. Noia: 175-388.

Kristiansen K., Larsson T. B. 2006. La Emergencia de la Sociedad del Bronce. Viajes, transmisiones y transformaciones. Bellaterra. Barcelona.

Kruta V., Kruta Poppi L. and Magni E. 2008. Gli occhi Della notte. Celti, Etruschi, Italici e la volta celeste. Skira. Milano.

Lambert P.-Y. 2008. Gaulois nemeton et atoś deuogdonion: deux noms de l'espace sacré. In X. Dupré Raventós, S. Ribichini and S. Verger (eds.), Saturnia Tellus. Definizioni dello spazio consacrato in ambiente etrusco, italico, fenicio-punico, iberico e celtico. Consiglio Nazionale delle Ricerche. Ufficio Pubblicazioni. Roma: 133-149.

Laurent D. 1995. La troménie de Locronan. Rite, espace et temps sacré. In Saint Ronan et la troménie. CRBC Association Abardaeziou Lokorn. Locronan: 11-57.

Lejeune M. 1985. Recueil des inscriptions gauloises I, Textes gallo-grecs. Centre National de la Recherche Scientifique. Paris.

1988. Recueil des inscriptions gauloises II, 1, Textes gallo-étrusques; Textes gallo-latins sur pierre. Centre National de la Recherche Scientifique. Paris.

Levinson S. C. 2003. Space in Language and Cognition. Cambridge University Press. Cambridge.

Lorrio A. J., Sánchez de Prado M. D. 2007. Las placas ornamentales de la necrópolis celtibérica de Arcóbriga (Monreal de Ariza, Zaragoza). Anales de Arqueología Cordobesa 18: 123-156.

Lorrio A. J., Ruiz Zapatero G. 2005. The Celts in Iberia: An Overview. e-Keltoi, Volume 6. The Celts in the Iberian Peninsula: 167-254. online (February 1, 2005): http://www4.uwm.edu/celtic/ekeltoi/volumes/vol6/6_4 /lorrio_zapatero_6_4.html

Loth J. 1904. L'année celtique d'après les textes irlandais gallois bretons et le calendrier de Coligny. Revue Celtique 25: 113-162.

Magdelain A. 1990. L'auguraculum de l'arx à Rome et dans d'autres villes. In A. Magdelain, Ius, Imperium, Auctoritas. Études se droit romain. Classiques de l'Ecole française de Rome. Roma, Paris: 193-207.

MacNeill M. 1962. The Festival of Lughnasa. A study of the Survival of the Celtic Festival of the Beginning of Harvest. Oxford University Press. Oxford.
Marco Simón F. 1994. La religión indígena en la Hispania indoeuropea. In J. M. Blazquez (ed.), Historia de las Religiones de la Europa Antigua. Cátedra. Madrid: 313-400.

Marco F., Alfayé S. 2008. El santuario de Peñalba de Villastar (Teruel) y la romanización religiosa en la Hispania indoeuropea. In X. Dupré Raventós, S. Ribichini and S. Verger (eds.), Saturnia Tellus. Definizioni dello spazio consacrato in ambiente etrusco, italico, fenicio-punico, iberico e celtico. Consiglio Nazionale delle Ricerche. Ufficio Pubblicazioni. Roma: 507-525.

Marshack A. 1985. A Lunar-Solar Year Calendar Stick from North America. American Antiquity 50(1): 27-51.

Megaw J. V. S., Megaw M. R. 1996. Ancient Celts and modern ethnicity. Antiquity 70: 175-181.

Merriman N. 1987. Value and motivation in prehistory; the evidence for 'Celtic spirit'. In I. Hoder (ed.), The Archaeology of Contextual Meanings. Cambridge University Press. Cambridge: 111-116.

McCluskey S. C. 1989. The Mid-Quarter Days and the Historical Survival of British Folk Astronomy. Archaeoastronomy 13, suppl. to Journal for the History of Astronomy 20: $\$ 1-S 19$

1990. The solar year in the Calendar of Cligny. Etudes Celtiques 27: 163-174.

Nash D. 1976. Reconstructing Poseidonios' Celtic Ethnography: Some Considerations. Britannia 7: 111-126.

Nilsson M. P. 1920. Primitive Time-Reckoning. C. W. K. Gleerup. Lund.

Parcero Oubiña C., Santos Estévez M. and Criado Boado F. 1998. Rewriting landscape: incorporating sacred landscapes into cultural traditions. World Archaeology 30: 159-176.

Peña Santos A. de la, Rey García J. M. 2001. Petroglifos de Galicia. Vía Láctea Editorial. Perillo.

Peña Santos A. de la, Vázquez Varela J. M. 1996. Los Petroglifos Gallegos. Edicions do Castro. Sada.

Pérez Gutiérrez M. 2008. Astronomía en la Edad del Hierro Peninsular. Orientaciones astronómicas en los castros celtas de la provincia de Ávila. Unpublished PhD thesis. Universidad de Salamanca. Salamanca.

Pérez M., Burillo F. 2009. Astronomical Alignments in Segeda. In M. Shaltout, O. Fikry (eds.), From Alexandria to Al.Iskandariya, astronomy and culture in the Ancient Mediterranean and Beyond. Submitted. 
Prósper M. B. 2002. Lenguas y religiones prerromanas del occidente de la Península Ibérica. Universidad de Salamanca. Salamanca.

Rodríguez G., Cerdeño M. L., Folgueira M. and Hernández M. C. 2007. A Multidisciplinary study applied to a Celtiberian site: preliminary results. In M. P. Zedda, J. A. Belmonte (eds.), Light and Shadows in Cultural Astronomy. Associazione Archeofila Sarda. Isili: 124-130.

Ruggles C. 2011. Pushing back the frontiers or still running around the same circles? 'interpreting archaeoastronomy' thirty years on. In C. L. N. Ruggles (ed.), Archaeoastronomy and Ethnoastronomy: building bridges across cultures. IAU Symposium 178. Cambridge University Press. Cambridge: 1-18.

Santos Estévez M. 2005. La caza ritual en la Edad del Bronce y su representación en el Arte Rupestre de Galicia. In M. Santos, A. Troncoso (eds.), Reflexiones sobre el Arte Rupestres, Paisaje, Forma y Contenido. Traballos de Arqueoloxía e Patrimonio 33: 83-100.

2008a. A New Proposal for the Chronology of Atlantic Rock Art in Galicia (NW Iberian Peninsula). In G. Nash, G. Children (eds.), The Archaeology of Semiotics and the Social Order of Things. British Archaeological Reports IS 1833. Archaeopress. Oxford: 141-152.

2008b. Petroglifos y paisaje social en la prehistoria reciente del noroeste de la Península Ibérica. CSIC-
XUGA-Instituto de Estudios Gallegos Padre Sarmiento. Santiago.

Santos M. J. Correia 2010. Santuários rupestres no Ocidente da Hispania indo-europeia. Ensaio de tipologia e classificação. Paleohispanica 10: 147-172.

Sergent B. 2005. L'interdit sur l'écriture chez les peuples indo-européens. Studia Indo-Europaea 2: 19-35.

Sims-Williams P. 1998. Celtomania and Celtoscepticism. Cambrian Medieval Celtic Studies 36: 1-35.

Sobrino Buhigas R. 2000. Corpus Petroglyphorum Gallaeciae. Editorial do Castro. Sada.

Sperber D. 1975. Pourquoi les animaux parfaits, les hybrides et les monstres sont-ils bons à penser symboliquement? L'Homme 15(2): 5-34.

Tierney J. J. 1960. The Celtic Ethnography of Posidonius. Proceedings of the Royal Irish Academy 40: 189-275.

Valdes L. 2005. El santuario protohistórico de Gastiburu (siglos IV al I a.C.) y el calendario estacional (Arratzu, Bizkaia). Munibe 57: 333-343.

Vives J. 1963. Concilios visigóticos e hispano romanos. Consejo Superior de Investigaciones Científicas. Barcelona. 
